\title{
Flexural Behavior of RC Beams Strengthened with Carbon Fiber Reinforced Polymer (CFRP) Fabrics
}

\author{
R. Balamuralikrishnan ${ }^{1, *}$ and C. Antony Jeyasehar ${ }^{2}$
}

\author{
${ }^{1}$ Senior Lecturer, ${ }^{2}$ Professor and Head, Department of Civil and Structural Engineering, Annamalai University, \\ Annamalainagar - 608 002, Tamilnadu, India
}

\begin{abstract}
This paper explores the flexural behavior of carbon fiber reinforced polymer (CFRP) strengthened reinforced concrete (RC) beams. For flexural strengthening of RC beams, total ten beams were cast and tested over an effective span of $3000 \mathrm{~mm}$ up to failure under monotonic and cyclic loads. The beams were designed as under-reinforced concrete beams. Eight beams were strengthened with bonded CFRP fabric in single layer and two layers which are parallel to beam axis at the bottom under virgin condition and tested until failure; the remaining two beams were used as control specimens. Static and cyclic responses of all the beams were evaluated in terms of strength, stiffness, ductility ratio, energy absorption capacity factor, compositeness between CFRP fabric and concrete, and the associated failure modes. The theoretical moment-curvature relationship and the load-displacement response of the strengthened beams and control beams were predicted by using FEA software ANSYS. Comparison has been made between the numerical (ANSYS) and the experimental results. The results show that the strengthened beams exhibit increased flexural strength, enhanced flexural stiffness, and composite action until failure.
\end{abstract}

Keywords: Composite beams, CFRP Fabric, Flexural Strengthening, Numerical (ANSYS), Reinforced Concrete.

\section{INTRODUCTION}

In recent years repair and retrofit of existing structures such as buildings, bridges, etc., have been amongst the most important challenges in Civil Engineering. The primary reason for strengthening of structures includes upgrading of its resistance to withstand underestimated loads, increase in the load carrying capacity for higher permit loads, such as due to increased perceived risk from seismic excitations, eliminating premature failure due to inadequate detailing, restoration of lost load carrying capacity due to corrosion or other types of degradation caused by aging, etc. The use of carbon fiber reinforced polymer (CFRP) in strengthening reinforced concrete (RC) structures has become an increasingly popular retrofit technique. The technique of strengthening reinforced concrete structures by externally bonded CFRP fabric was started in 1980s and has since attracted researchers around the world [1].

Strengthening with externally bonded CFRP fabric has shown to be applicable to many kinds of structures. Currently, this method has been applied to strengthen such structures as column, beams, walls, slabs, etc. The use of external CFRP reinforcement may be classified as flexural strengthening, improving the ductility of compression members, and shear strengthening. It is well known that reinforced concrete beams strengthened with externally bonded fiber-reinforced polymer (FRP) or CFRP to the tension face can exhibit ultimate flexural strength greater

*Address correspondence to this author at the Department of Civil and Structural Engineering, Annamalai University, Annamalainagar - 608 002, Tamilnadu, India; Tel: 91- 4144- 239732;

E-mail: bmk_gaya@rediffmail.com than their original flexural strength. However, these FRP and CFRP strengthened beams could lose some of their ductility due to the brittleness of FRP and CFRP plates. Reinforced concrete beams were Strengthened with Glass FiberReinforced Polymers (GFRP) or FRP plates [2, 3]. They concluded that the flexural strength of reinforced concrete beams could be significantly increased by externally bonded GFRP of FRP plated to their tension surface. However, they indicted in their experimental research that the ductility of reinforced concrete beams using externally bonded GFRP or FRP was reduced, and the extent of reduction in ductility was dependent upon the original beams.

A relatively new technique involves replacement of the steel plates by fiber-reinforced polymers (FRP) in the form of fabric or wraps [4-8]. FRP offers the engineers an outstanding combination of properties such as low weight, easier site handling, immunity from corrosion, excellent mechanical strength and stiffness, and the ability of formation in long lengths, thus eliminating the need for lap joints. Further, there has been a rapid progress in concrete technology that has resulted in the evolution of concretes having specified characteristics. The present study evaluates the performance of RCC beams with bonded CFRP fabric in single layer and two layers at the soffit of the beam under static and cyclic loading. CFRP fabric has shown great promise to upgrade structural systems. An emphasis has been given to the strength and deformation properties of CFRP fabric strengthened RC beams. The theoretical moment-curvature relationship and the load - displacement response of the strengthened beams and control beams were predicted by using FEA software ANSYS. Comparison is made between the numerical (ANSYS) and the experimental 
results and suitable conclusions are drawn based on the results obtained from laboratory experiments and numerical analysis.

\section{EXPERIMENTAL INVESTIGATION}

The test program consisted of casting and testing of ten beams, of which two were control beams, all having size of $150 \times 250 \times 3200 \mathrm{~mm}$ length and designed as the beams of under reinforced section [9], reinforced with 2-12 \# at bottom, 2-10 \# at top using 6mm dia stirrups @ $150 \mathrm{~mm} \mathrm{c} / \mathrm{c}$ (Fig. 1). The beams were cast using M 20 grade concrete and Fe 415 grade steel.

Ordinary Portland cement, natural river sand and the crushed granite of maximum size $20 \mathrm{~mm}$ were used. High yield strength deformed (HYSD) bars of 12 and $10 \mathrm{~mm}$ diameter with mean strength of $512 \mathrm{~N} / \mathrm{mm}^{2}$ were used as

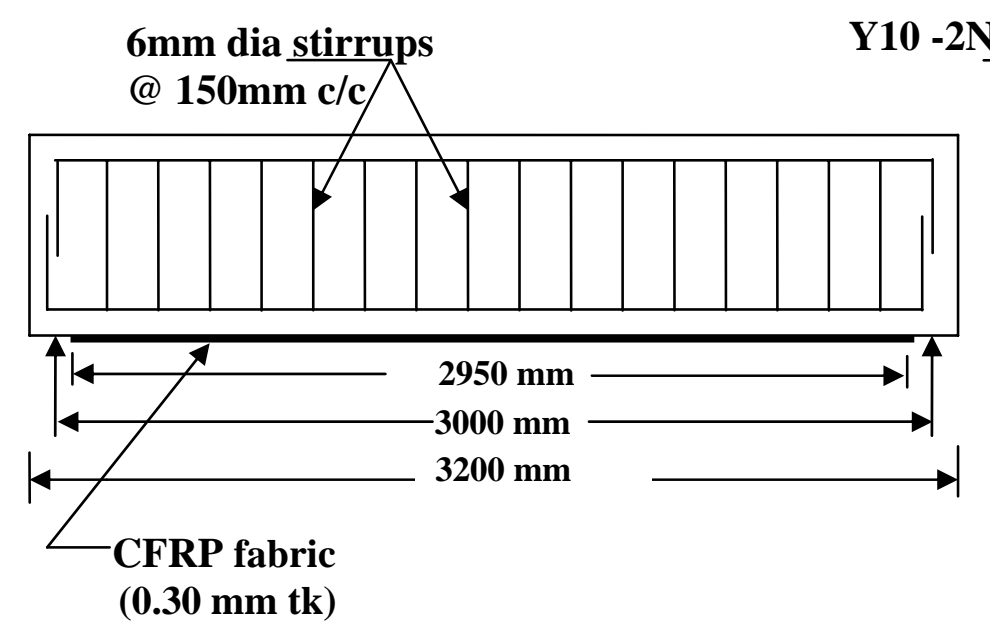

Longitudinal Section longitudinal reinforcement and $6 \mathrm{~mm}$ diameter mild steel bars were used for internal links. The elastic modulus of the concrete is $2.4 \times 10^{4} \mathrm{~N} / \mathrm{mm}^{2}$. After 28-day curing, companion cubes $(150 \mathrm{~mm})$ and cylinders $(150 \mathrm{~mm}$ diameter x $300 \mathrm{~mm}$ height) cast along with the beams were tested in compression to determine the 28-day compressive strength and modulus of elasticity. In two series of strengthened beams, first series having four beams with bonded CFRP fabric in single layer which is parallel to beam axis of which two beams were subjected to static loading, and remaining two beams were subjected to compression cyclic loading. In second series having four beams with bonded CFRP fabric in two layers which are parallel to beam axis of which two beams were subjected to static loading and remaining two beams were subjected to compression cyclic loading under virgin condition and tested until failure. The details of test beams are presented in Table $\mathbf{1}$.

Fig. (1). Longitudinal and Cross Section of Strengthened Beam

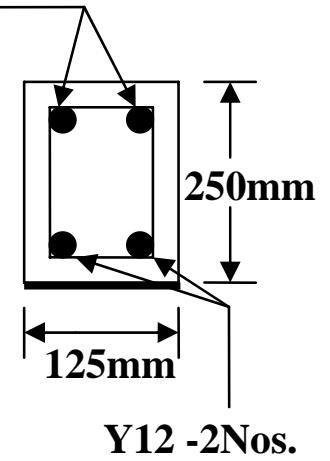

$\underline{\text { Cross Section }}$

Table 1. Beam Designation

\begin{tabular}{|c|c|c|c|c|c|c|c|c|}
\hline \multirow[t]{2}{*}{ Sl. No } & \multirow[t]{2}{*}{$\begin{array}{c}\text { Beam } \\
\text { Number }\end{array}$} & \multirow[t]{2}{*}{ Beam Type } & \multicolumn{2}{|c|}{ Loading Set Up } & \multicolumn{4}{|c|}{$\begin{array}{l}\text { CFRP Fabric Properties }\left(0.30 \mathrm{~mm} \text { Thickness }, 200 \mathrm{~g} / \mathrm{m}^{2}\right. \\
\left.\text { Weight of Fiber and } \mathrm{E}=1.55 \times 10^{5} \mathrm{~N} / \mathrm{mm}^{2}\right)\end{array}$} \\
\hline & & & $\begin{array}{c}\text { Static } \\
\text { Loading }\end{array}$ & $\begin{array}{l}\text { Cyclic Loading } \\
\text { (Compression } \\
\text { Cyclic) }\end{array}$ & Fiber Orientation & $\begin{array}{c}\text { Tensile } \\
\text { StrengthN/mm }\end{array}$ & $\begin{array}{c}\text { Tensile } \\
\text { Modulus } \\
\text { N/mm }\end{array}$ & $\begin{array}{c}\text { Ultimate } \\
\text { Elongation in } \\
\text { Percentage }\end{array}$ \\
\hline 1. & $\mathrm{CB} 1$ & Control Beam & 1 No. & - & - & - & - & - \\
\hline 2. & $\mathrm{CB} 2$ & Control Beam & - & $1 \mathrm{No}$. & - & - & - & - \\
\hline 3. & RB1 & $\begin{array}{c}\text { CFRP } \\
\text { Strengthened beam } \\
\text { (Single layer) }\end{array}$ & 2 Nos. & - & $\begin{array}{l}\text { Unidirectional } \\
\text { (Parallel to } \\
\text { beam axis) }\end{array}$ & 3500 & $285 \times 10^{3}$ & 1.50 \\
\hline 4. & $\mathrm{RB} 2$ & $\begin{array}{c}\text { CFRP } \\
\text { Strengthened beam } \\
\text { (Single layer) }\end{array}$ & - & 2Nos. & $\begin{array}{l}\text { Unidirectional } \\
\text { (Parallel to } \\
\text { beam axis) }\end{array}$ & 3500 & $285 \times 10^{3}$ & 1.50 \\
\hline 5. & RB3 & $\begin{array}{c}\text { CFRP } \\
\text { Strengthened beam } \\
\text { (Two layers) }\end{array}$ & 2Nos. & - & $\begin{array}{l}\text { Unidirectional } \\
\text { (Parallel to } \\
\text { beam axis) }\end{array}$ & 3500 & $285 \times 10^{3}$ & 1.50 \\
\hline 6. & RB4 & $\begin{array}{c}\text { CFRP } \\
\text { Strengthened beam } \\
\text { (Two layers) }\end{array}$ & - & 2Nos. & $\begin{array}{l}\text { Unidirectional } \\
\text { (Parallel to } \\
\text { beam axis) }\end{array}$ & 3500 & $285 \times 10^{3}$ & 1.50 \\
\hline
\end{tabular}


The CFRP fabric (Nitowrap EP (CF) from Fosroc Chemicals Limited) available in coil form of standard width of $1.0 \mathrm{~m}$ and orientation of fiber is unidirectional shown in Fig. (2).

The soffit of the beams were sand blasted to remove the surface laitance and then blown free of dust using compressed air. The CFRP fabric from is a carbon fiber composite wrapping system were adopted, in which Nitowrap (CF) is used in conjunction with an epoxy sealer cum primer Nitowrap 30 applied over the soffit of the beam, allow them to dry and then apply as a high build epoxy saturant Nitowrap 410 over the primer coat. The high build epoxy pot life is 2 hours at $30^{\circ} \mathrm{C}$. The CFRP fabric in single layer cut to the size of $125 \times 0.3 \times 2950 \mathrm{~mm}$ was placed over the beam which is parallel to beam axis and the uniform pressing was done by grip roller head. The system is protected by a polyurethane top coat of Nitowrap 512 in case of atmospherically exposed structure. The strengthened beams were tested after the interval of 7-days. The coin tap was conducted to identify areas of debond, if any. The same procedure was adopted bonding CFRP fabric in two layers one over the other which are parallel to beam axis and finished protective coating over second layer shown in Fig. (3).

Load, displacement and strains have been recorded. For each specimen electrical strain gauges were fixed at mid span of tension reinforcement and at the mid span of bottom surface of bonded CFRP fabric in the longitudinal direction. Concrete having mean cube compressive strength of 27.54 MPa was used. For all the test beams, the parameters of interest were ultimate load, mid-span deflection, 1/3 span (both left and right) deflections, composite action, and failure modes. All the test beams were over-designed for shear to avoid the undesirable brittle failure. The CFRP fabric thickness of $0.3 \mathrm{~mm}$ and bond line thickness of 300 microns were kept constant for all the test specimens.

\subsection{Testing and Measurements}

All the beams were tested over a simply supported span of $3000 \mathrm{~mm}$ under four-point bending, the load of which was monotonically increased under static loading and compression cyclic loading. (Figs. 4, 5). The vertical mid-span and $1 / 3^{\text {rd }}$ span deflections were measured using mechanical dial gauges of $0.01 \mathrm{~mm}$ accuracy and electrical strain gauges were used for finding the steel strain and composite strain. The crack development and propagation were monitored and marked during the progress of the test. The crack widths

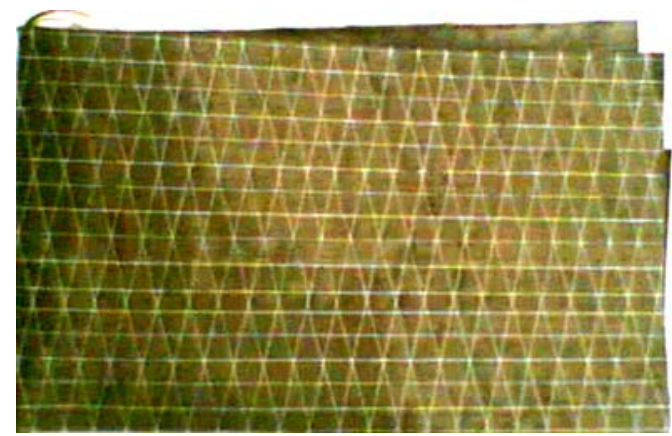

were measured using a crack detection microscope of 0.02 $\mathrm{mm}$ precision.

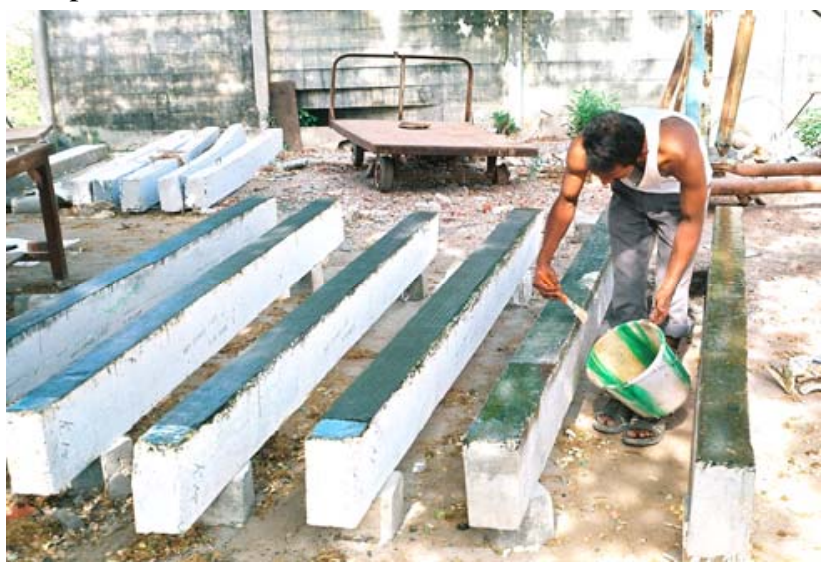

Fig. (3). Finished with Protective Coating Over Second Layer.

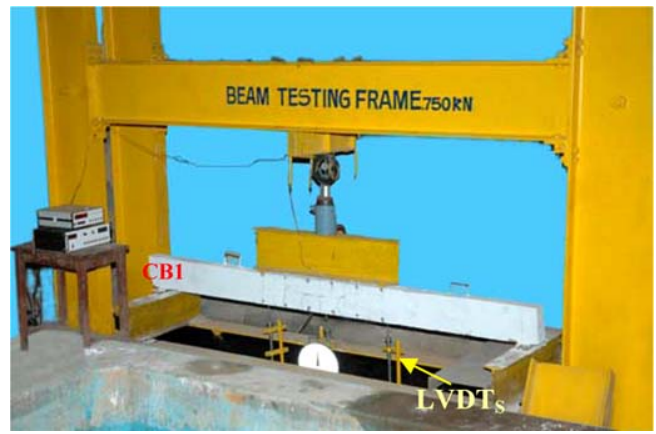

Fig. (4). Test Set Up for Static Loading.

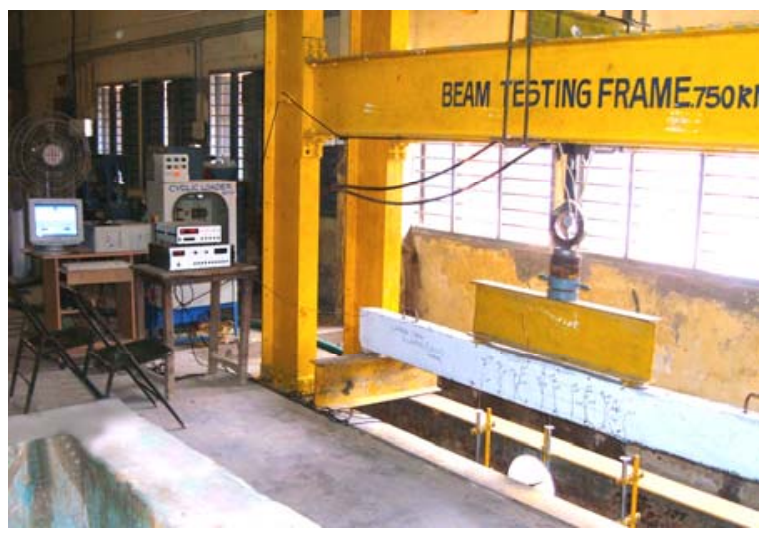

Fig. (5). Test Set Up for Compression Cyclic Loading.

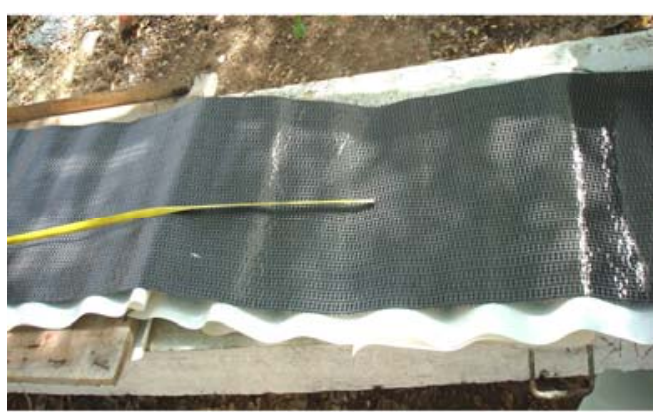

Fig. (2). Carbon Fiber. 


\subsection{Summary of Test Results}

The test results on the strength and deformation properties of the control specimens and strengthened beams are reported in Tables $\mathbf{2}$ and $\mathbf{3}$.

The quantitative measure of ductility has to be with reference to the load-deflection response. Then, the ratio of the ultimate deformation to the deformation at the beginning of the horizontal path (or, at first 'yield') can give a measure of ductility. However, each choice of deformation (strain, rotation, curvature, or deflection) may give a different value for the ductility measure [10].

Energy absorption capacity can be measured under the area of stress-strain curve (load-deflection curve). The first crack loads were obtained by visual examination only. The experimental ultimate loads were obtained corresponding to the load beyond which the beam would not sustain additional deformation at the same load intensity. Based on the experimental results, it can be observed that significant increase in strength can be realized at all the load levels by externally bonding CFRP fabric. This increase may be attributed to the increase in tensile cracking strength of concrete due to confinement. Further, it is to be noted that increase in load carrying capacity is possible only when other modes of failure do not interfere. All the strengthened beams were also carefully examined prior to and after testing. It was found that failure did not occur at the CFRP fabric-concrete interface.
This confirms that the composite action continued throughout the load spectrum.

The details presented in Tables $\mathbf{2}$ and $\mathbf{3}$ show that the beam RB3 and RB4 are performing well in all respects but RB4 exhibited slight decrease in all the properties due to the sustained load effect. The load-mid span deflection graphs were drawn for control and strengthened beams both in static and compression cyclic loading as shown in Figs. (6-10). From the graph it is observed that beam RB3 exhibited increased flexural strength and decreased deflection.

During the test, the crack patterns in the beams were noted and the crack patterns were closely analyzed. The crack patterns of the beams are shown in Fig. (11) and also the crack width of the control beams and strengthened beams are reported in Tables $\mathbf{2}$ and $\mathbf{3}$.

\section{NUMERICAL (ANSYS) RESULTS OF LOAD- DEFLECTION BEHAVIOUR}

FEA software ANSYS is adopted for predicting the loaddisplacement response of the control and strengthened beams numerically. The mesh model defined 375 nodes and 47 elements. The programme offers solid 65 for beam element (Fig. 12), link 8 for steel element (Fig. 13) and solid 45 for CFRP fabric element [11]. The generated model for beams are $\mathrm{CB} 1, \mathrm{RB} 1$ and $\mathrm{RB} 3$. The element discretization, loading pattern and boundary conditions in FEA model (ANSYS) for

Table 2. Summary of Test Results

\begin{tabular}{|c|c|c|c|c|c|c|c|c|c|}
\hline \multirow{2}{*}{$\begin{array}{l}\text { Beam } \\
\text { Code }\end{array}$} & \multicolumn{2}{|c|}{ First Crack Stage } & \multicolumn{2}{|c|}{ Service Stage } & \multicolumn{2}{|c|}{ Yield Stage } & \multicolumn{2}{|c|}{ Ultimate Stage } & \multirow{2}{*}{$\begin{array}{c}\text { Average } \\
\text { Crack Width } \\
\text { at Service } \\
\text { Load }(\mathbf{m m})\end{array}$} \\
\hline & $\begin{array}{c}\text { Load } \\
(\mathbf{k N})\end{array}$ & $\begin{array}{c}\text { Central } \\
\text { Deflection }(\mathrm{mm})\end{array}$ & $\begin{array}{r}\text { Load } \\
(\mathbf{k N})\end{array}$ & $\begin{array}{c}\text { Central } \\
\text { Deflection }(\mathrm{mm})\end{array}$ & $\begin{array}{c}\text { Load } \\
(\mathrm{kN})\end{array}$ & $\begin{array}{c}\text { Central } \\
\text { Deflection }(\mathrm{mm})\end{array}$ & $\begin{array}{r}\text { Load } \\
(\mathbf{k N})\end{array}$ & $\begin{array}{c}\text { Central } \\
\text { Deflection }(\mathbf{m m})\end{array}$ & \\
\hline CB1 & 15 & 3.38 & 27.50 & 14.08 & 34.37 & 17.60 & 41.25 & 21.13 & 0.11 \\
\hline $\mathrm{CB} 2$ & 15 & 3.45 & 27.50 & 14.08 & 34.37 & 17.60 & 41.00 & 21.00 & 0.11 \\
\hline RB2 & 18.5 & 5.14 & 32.00 & 13.42 & 40.00 & 16.00 & 49.00 & 20.10 & 0.09 \\
\hline RB3 & 25.00 & 4.68 & 40.00 & 12.08 & 50.00 & 15.00 & 60.00 & 18.12 & 0.08 \\
\hline RB4 & 24.00 & 4.68 & 39.50 & 12.08 & 48.00 & 14.75 & 59.00 & 17.10 & 0.08 \\
\hline
\end{tabular}

Table 3.

\begin{tabular}{|c|c|c|c|c|}
\hline Beam Code & Ductility Factor & Energy Capacity Factor & $\begin{array}{c}\text { Post Cracking-Pre yielding } \\
\text { Stiffness (kNm })^{2}\end{array}$ & Mode of Failure \\
\hline \hline CB1 & 1.18 & 1.20 & 935 & Flexure \\
\hline CB2 & 1.16 & 1.19 & 1183 & Flexure \\
\hline RB1 & 1.25 & 1.75 & 1197 & Flexure \\
\hline RB2 & 1.30 & 1.80 & 1597 & Flexure \\
\hline RB3 & 1.38 & 2.00 & 1559 & Flexure \\
\hline RB4 & 1.42 & 2.00 & & \\
\hline
\end{tabular}




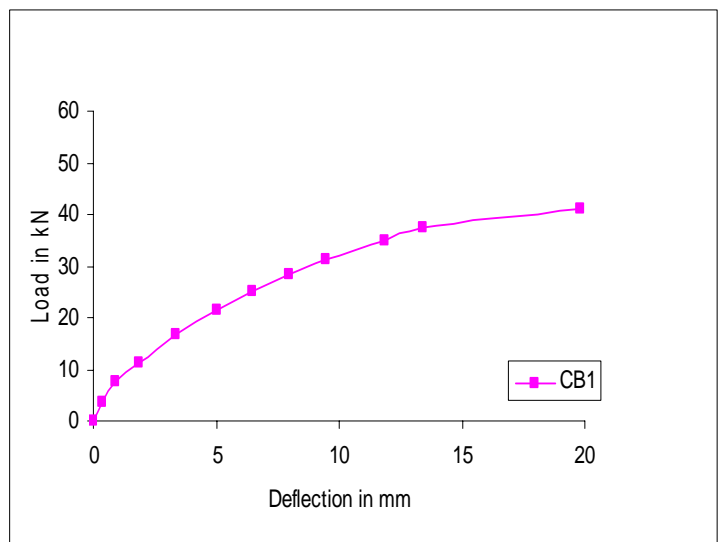

Fig. (6). Load-Deflection Curves for CB1 (Static Loading).

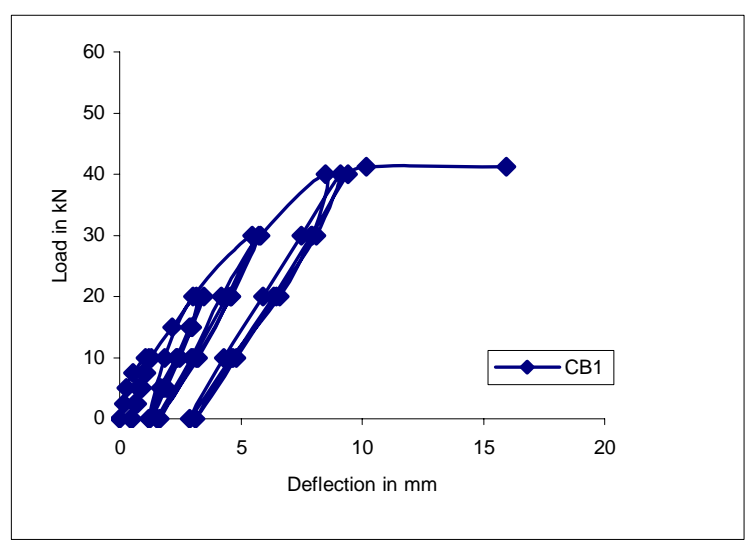

Fig. (7). Load-Deflection Curves for CB1 (Compression Cyclic Loading).

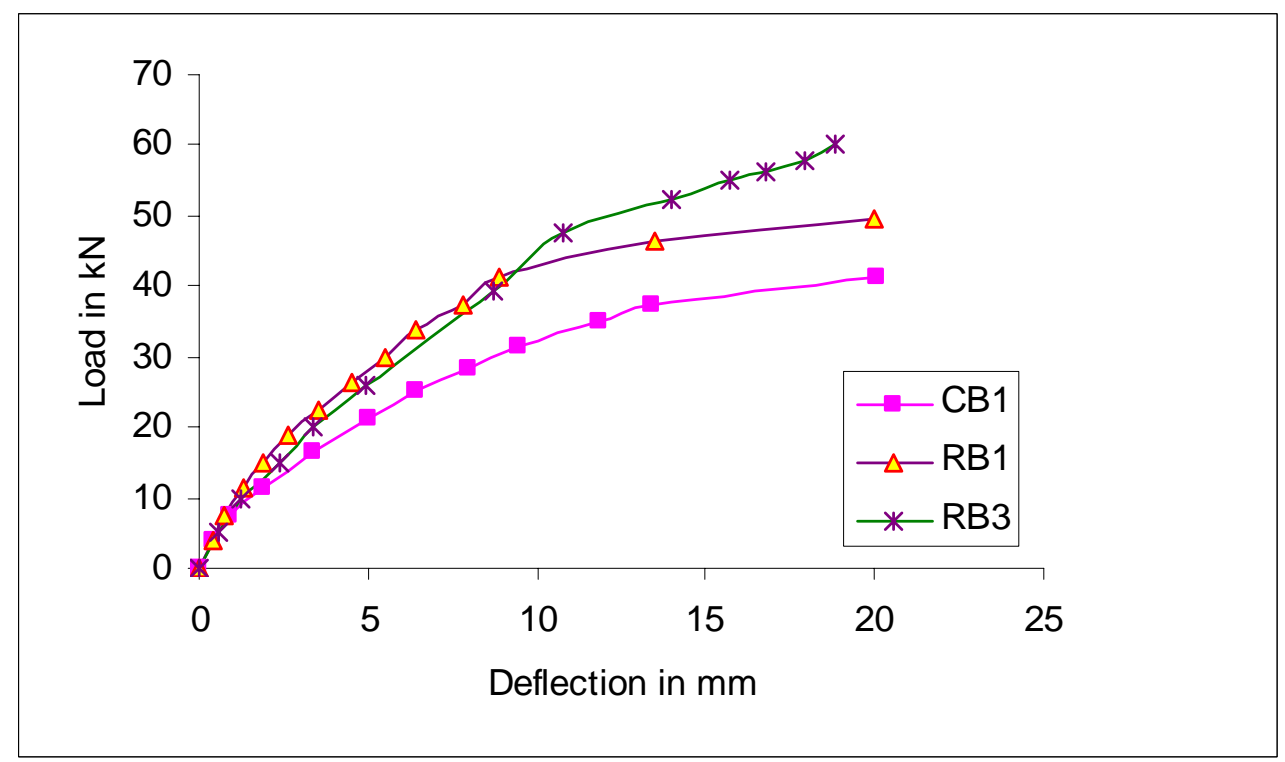

Fig. (8). Load deflection Curve for Control Beam and CFRP Strengthened Beams in Single and Double Layers (Static Loading).

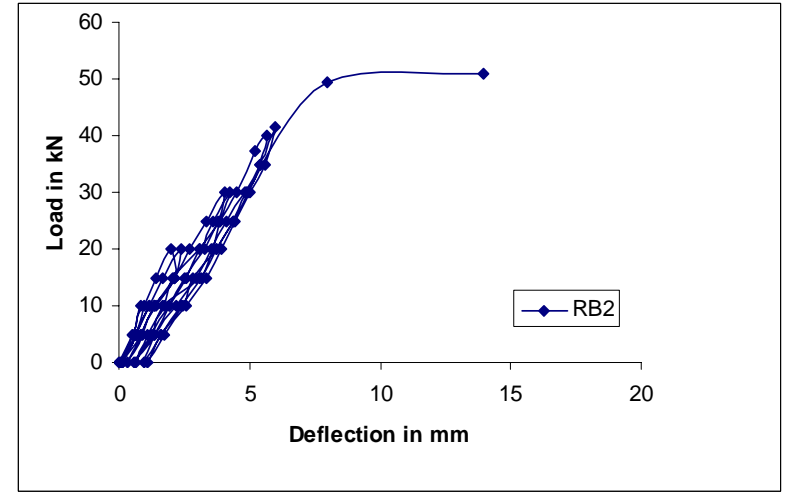

Fig. (9). Load deflection Curve for Single Layer CFRP Strengthened Beam RB2 (Compression Cyclic Loading).

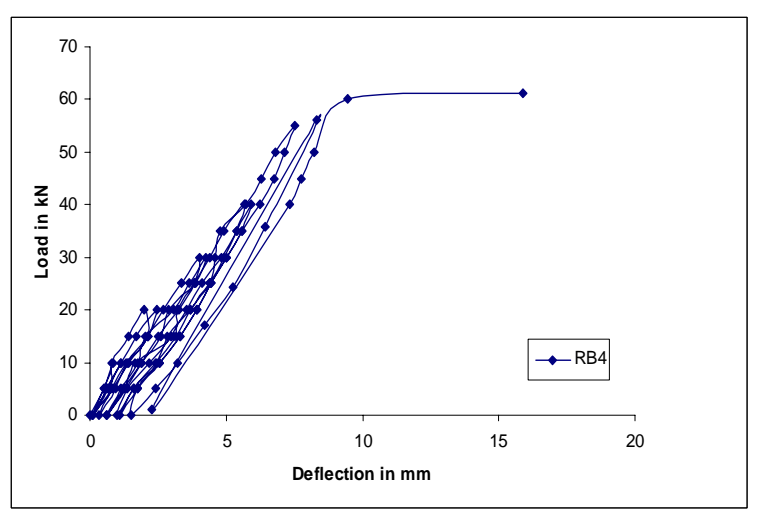

Fig. (10). Load deflection Curve for Single Layer CFRP Strengthened Beam RB4 (Compression Cyclic Loading). 

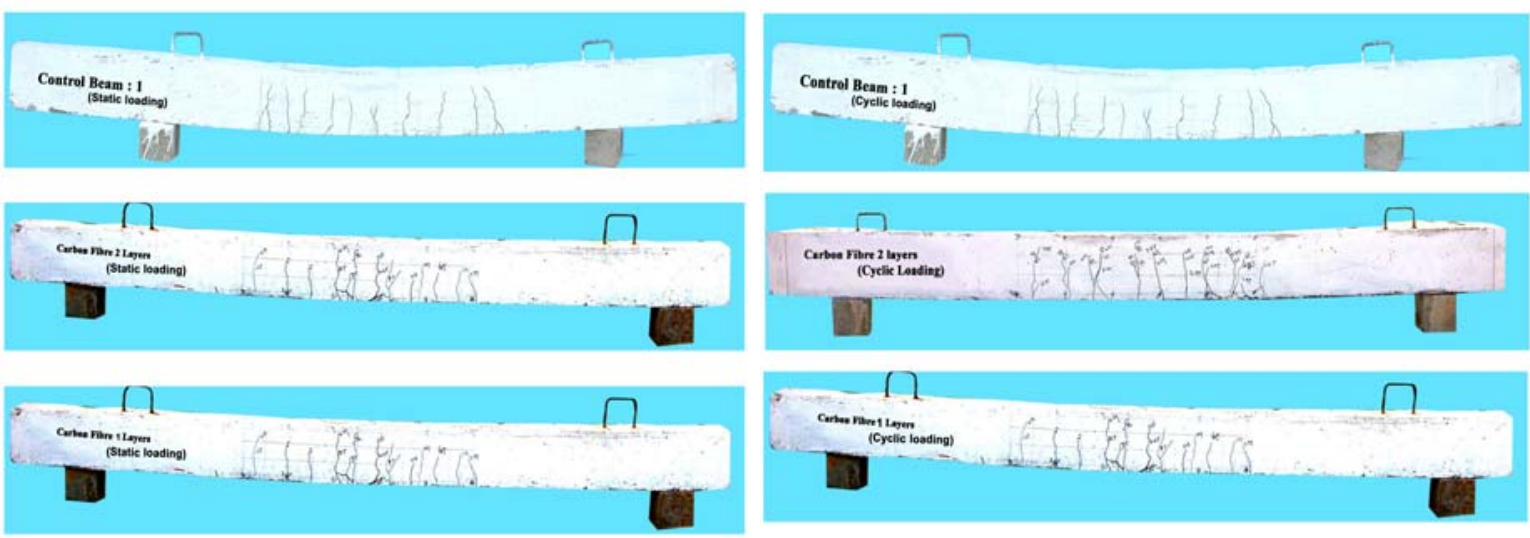

Fig. (11). Crack Pattern of Tested Beams (Static and Compression Cyclic Loading).

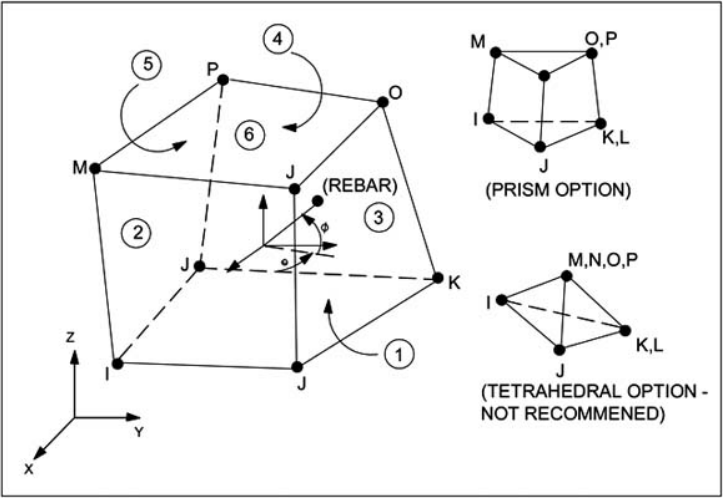

Fig. (12). Solid 65 and Solid 45 Geometry.

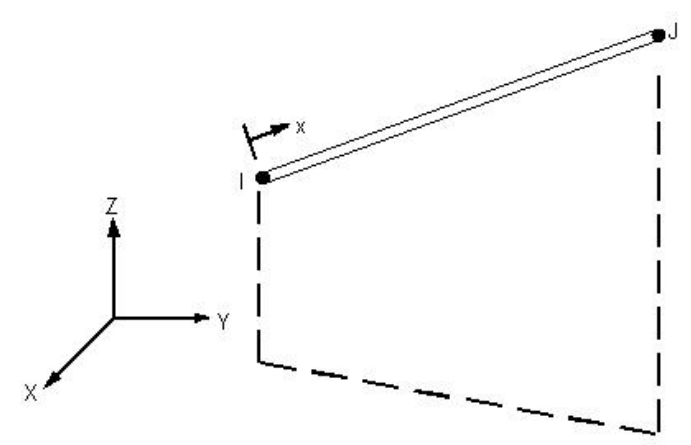

Fig. (13). Link 8 Geometry.

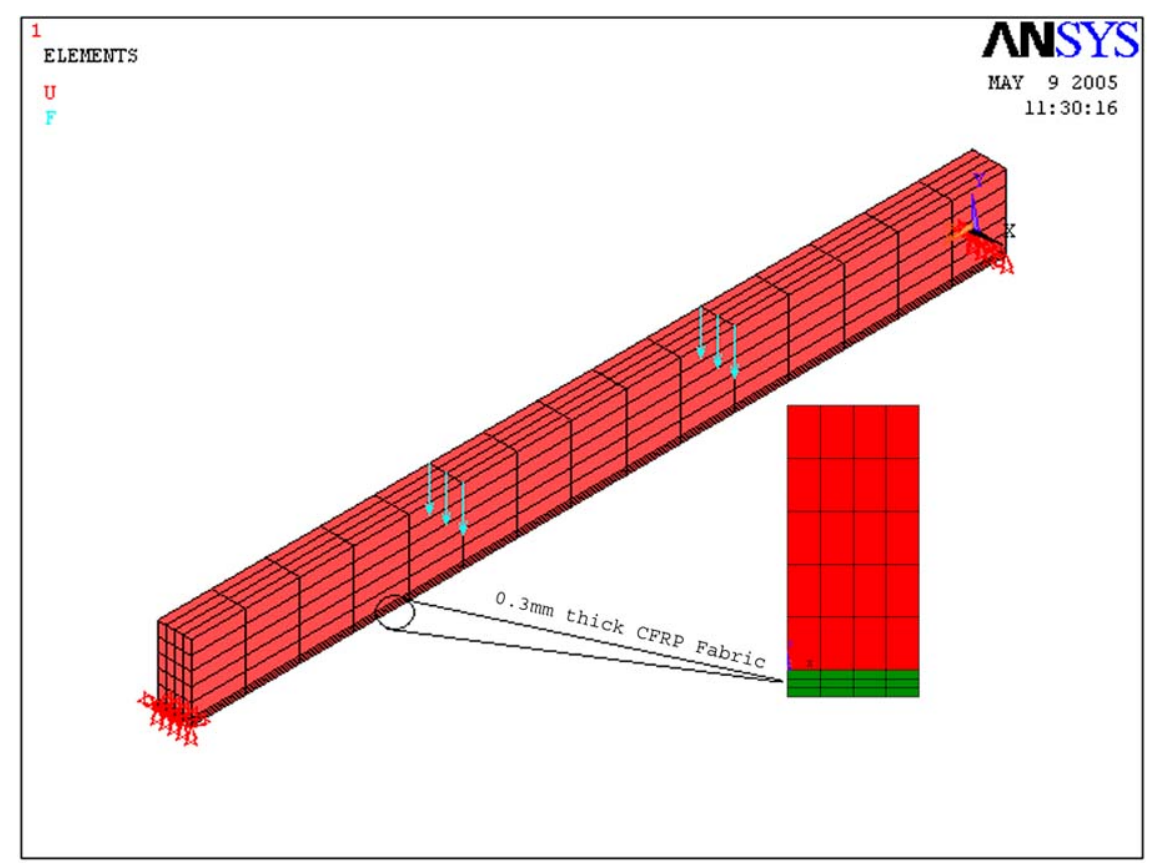

Fig. (14). Element Discretization, Loading Pattern and Boundary Conditions (RB3).

RB3 beam is shown in Fig. (14). A typical deflected shape at ultimate stage of strengthened beam (RB3) is shown in Fig. (15). The experimental and numerical (ANSYS) loaddeflection curves are compared for both control beam CB1 and strengthened beams RB1 and RB3 are shown in Fig.
(16). It can be seen that the predicted deflections are in close agreement with the experimental results. Comparisons of ultimate loads for experimental and numerical (ANSYS) results are shown in Table 4. 


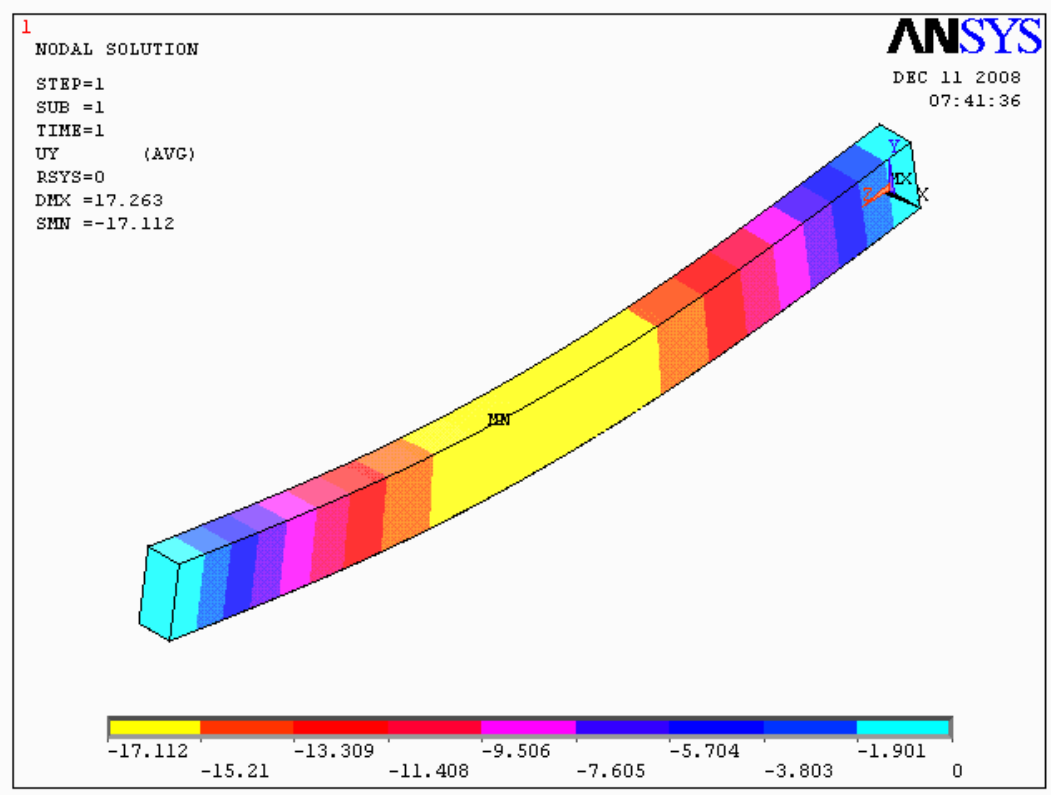

Fig. (15). Deflected Shape of Strengthened Beam RB3 at Ultimate Stage.

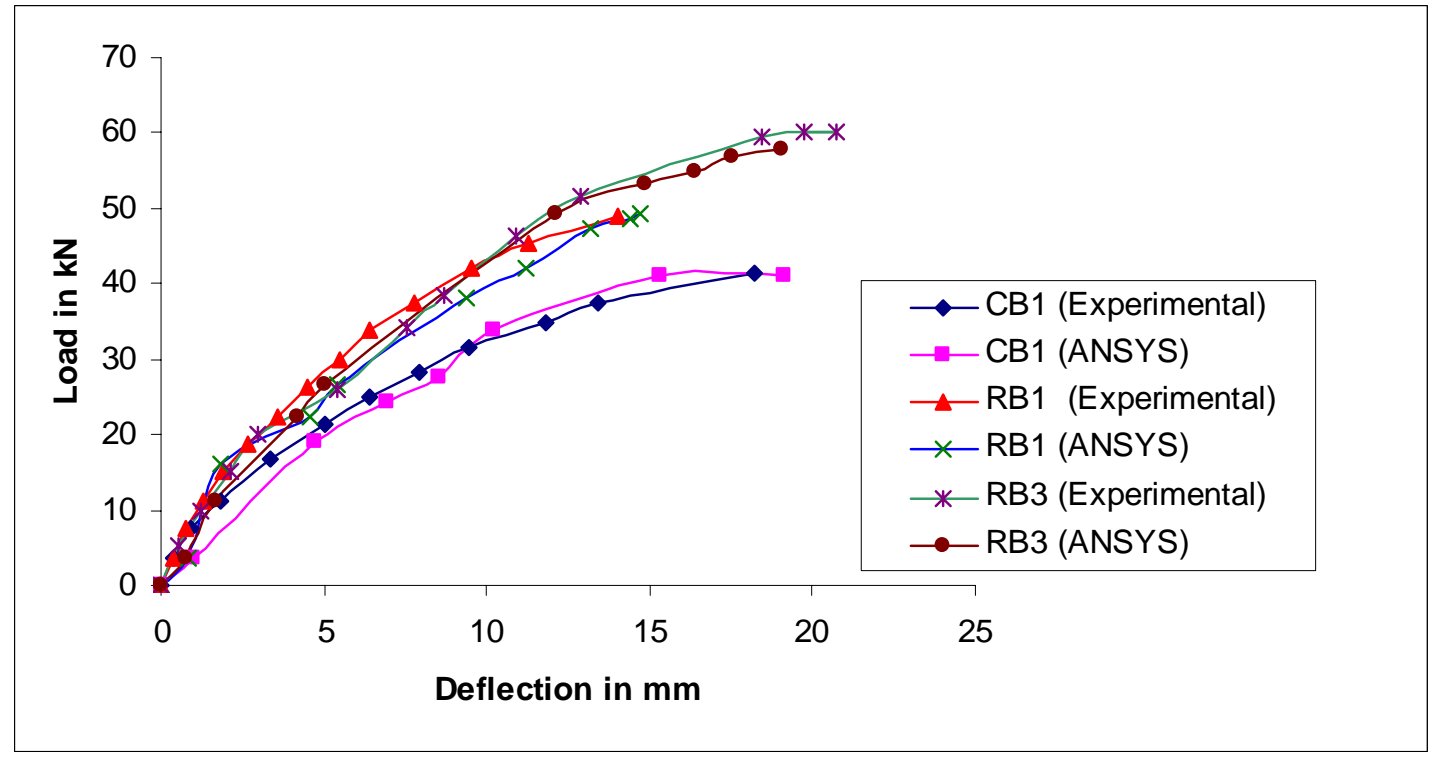

Fig. (16). Load - Deflection Curve for Control Beam CB1 and Strengthened beams RB1 and RB3.

Table 4. Comparisons of Ultimate Loads

\begin{tabular}{|c|c|c|c|c|c|}
\hline \multirow{2}{*}{ S1. No } & \multirow{2}{*}{ Detail of Beam } & \multicolumn{2}{|c|}{ Ultimate Loads in kN } & \multicolumn{2}{c|}{ Percentage Increase in Flexural Capacity } \\
\cline { 3 - 6 } & & Experimental & Numerical (ANSYS) & Experimental & Numerical (ANSYS) \\
\hline \hline 1. & CB1 & 41.25 & 41.00 & - & - \\
\hline 3. & RB1 & 49.50 & 49.00 & 20 & 18 \\
\hline 5. & RB3 & 60.00 & 58.00 & 45.00 & 41 \\
\hline
\end{tabular}




\section{CONCLUSIONS}

Based on the results obtained from experiments, and theoretical analyses, the following conclusions are drawn:

1. CFRP fabric properly bonded to the tension face of RC beams can enhance the flexural strength substantially. The strengthened beams exhibit an increase in flexural strength of 18 to 20 percent for single layer and 40 to 45 percent for two layers both static and compression cyclic loading respectively.

2. At any given load level, the deflections are reduced significantly thereby increasing the stiffness for the strengthened beams. At ultimate load level of the control specimens, the strengthened beams exhibit a decrease of deflection up to 80 percent.

3. All the beams strengthened with CFRP fabric in single layer and two layers experience flexural failures. None of the beams exhibit premature brittle failure.

4. A flexible epoxy system will ensure that the bond line both in single layer and two layers CFRP strengthened beams does not break before failure and participate fully in the structural resistance of the strengthened beams.

5. In this investigation CPRP strengthened beam gives appreciable ductility when compared to control beam.

6. From the experimental results it is clear that minimum two layers of CFRP fabric should be bonded to get the desired results. The strengthened beams RB1(single layer) and RB3 (two layer), exhibit 20 percent and 45 percent increase in flexural strength when compared to the control specimen and has close agreement with the experimental and numerical (ANSYS) results.

\section{REFERENCES}

[1] U. Meier, M. Deuring, H. Meier, and G. Schwegler, "Srtengthening of structures with CFRP strips: research and applications in Switzerland", Adv. Comp. Mat. Bridges Struct. Can. Soc. Civil Eng., Montreal and Canada., vol. 1, June 1992, pp. 243-251,.

[2] H.Saadatmanesh, and M.R. Ehasani, "RC beams strengthened with FRP plates-experimental study", ASCE J. Struct. Eng., vol. 117, no. 11, pp. 3417-3433, Nov 1997.

[3] M. Arduini, A. Di Tommaso, and A. Nanni,"Brittle failure in FRP plate and sheet bonded beams", ACI Struct. J., vol. 94, no. 4, pp. 363-370, July-Aug 1997.

[4] U. Meier. Bridge Repair with high performance Composite Materials, Ricerca Italiana: Material and Technic, 1987.

[5] T.C. Triantafillou,"Shear strengthening of reinforced concrete beams using epoxy bonded FRP composites", ACI Struct. J., vol. 95, no. 2, pp.107-115, Mar-April 1998.

[6] A.M. Malek, and H. Saadmatmanesh,"Ultimate shear capacity of reinforced concrete beams strengthened with web-bonded fiber reinforced plastic plates", ACI Struct. J., vol. 95, no. 4, pp. 391-399, Nov 1998.

[7] T. Norris, H. Saadatmanesh, and M.R. Ehsani, "Shear and flexure strengthening of RC beams with carbon fiber sheets", ASCE J. Struct. Eng., vol. 123, no. 7, pp. 903-911, Dec 1996.

[8] T. Tang, and H. Saadatmanesh, "Retrofit of concrete beams strengthened with FRP laminates against impact", CONMAT, vol. 1, pp. 84-94, Aug 2003.

[9] IS 456, Code of practice for reinforced concrete design, New Delhi: Bureau of Indian Standards, 2000.

[10] U. Pillai, and D. Menon, Reinforced concrete design, New Delhi: McGraw-Hill Publishing Co Ltd., 2002.

[11] User Manual, ANSYS 8, USA: Ansys. Inc. Houston, 2006. 